\title{
Degradation by bacteria of membrane and soluble protein in seawater
}

\author{
Toshi Nagata $^{1, *}$, Rumi Fukuda $^{1}$, Isao Koike ${ }^{1}$, Kazuhiro Kogure $^{1}$, David L. Kirchman ${ }^{2}$ \\ 'Ocean Research Institute, University of Tokyo, 1-15-1 Minami-dai, Nakano, Tokyo 164, Japan \\ ${ }^{2}$ College of Marine Studies, University of Delaware, Lewes, Delaware 19958, USA
}

\begin{abstract}
In order to test the hypothesis that bacterial membrane protein is more slowly degraded than soluble protein in seawater, we examined degradation by natural bacterioplankton of membrane and soluble proteins prepared from the marine bacterium Vibrio alginolyticus radiolabeled with ${ }^{3} \mathrm{H}$ - or ${ }^{14} \mathrm{C}$-leucine. First order kinetic constants indicated that proteins in crude membrane extract are degraded at significantly slower rates $(1 / 2$ to $1 / 6)$ than the soluble proteins. Proteins determined to be intimately associated with the membrane were not degraded during the initial $45 \mathrm{~h}$, while a substantial fraction of soluble proteins was degraded during the same period. The data are consistent with a model in which membrane and cell wall materials severely restrict access of bacterial proteases to membrane proteins. After prolonged incubation, however, membrane proteins started to be degraded, suggesting that proteins protected by membrane components were made available for degradation after ectoenzymatic destruction of membrane components. Our data support the hypothesis that macromolecular organic complexes play a role in temporary storage of dissolved organic matter (DOM) in seawater and that complementary hydrolysis by different ectoenzymes produced by diverse bacterioplankton is important in determining rates and patterns of DOM degradation in the sea.
\end{abstract}

KEY WORDS: Protein degradation · Marine bacteria $\cdot$ Dissolved organic matter

\section{INTRODUCTION}

Dissolved combined amino acids (DCAA) represent the largest identified component of dissolved organic nitrogen in seawater (Keil \& Kirchman 1993) and play important roles in carbon and nitrogen cycling within marine environments. Previous studies using radiolabeled algal proteins have indicated that the turnover rate of these proteins in seawater is high (on the order of hours to days), not much slower than the turnover of dissolved free amino acids (Coffin 1989, Keil \& Kirchman 1993). Proteolytic enzymes bound to bacterial cells are suggested to be responsible for high turnover of dissolved proteins (Hollibaugh \& Azam 1983). Other data, however, have indicated that a substantial fraction of the dissolved protein pool in seawater is refractory (Tanoue 1997), suggesting that some protein components are resistant to enzymatic attack and

\footnotetext{
·E-mail:nagata@ori.u-tokyo.ac.jp
}

accumulate in seawater. Mechanisms underlying variation in degradability of dissolved proteins and other dissolved organic compounds in seawater are not well understood.

One hypothesis is that labile protein is transformed into less labile protein due to abiotic modifications including adsorption, condensation and photochemical reactions (Hedges 1988, Keil \& Kirchman 1994, Nagata \& Kirchman 1996). An alternative, if not mutually exclusive, hypothesis is that selected components of cellular material do not need modification in order to resist microbial degradation and thus are selectively preserved in seawater while other material is degraded. Recent research has suggested that dissolved proteins in oceanic waters are dominated by only a limited number $(<30)$ of protein molecules, one of which was identified to be a bacterial outer membrane protein, porin (Tanoue et al. 1995, 1996). However, the mechanism by which porins and other membrane proteins are selectively preserved in seawater is not clear. 
Previous work has identified processes that produce membrane fragments which probably contain porins and other bacterial membrane proteins. Nagata \& Kirchman (1992) showed that large numbers of bacterial membrane fragments can be produced during egestion of protists feeding on bacteria. Lysis by viruses of bacterial and other microbial cells also would produce membrane fragments. Fragments produced by protist grazing or viral lysis could form vesicles with liposomelike structures. These macromolecular complexes may be one source of less labile dissolved organic matter in seawater (Nagata \& Kirchman 1992, 1997), although the degradation of these complexes has not been examined.

In order to begin to examine the degradation of macromolecular complexes, here we tested the hypothesis that bacterial membrane protein is more slowly degraded than soluble protein in seawater. We examined degradation by bacteria of membrane and soluble proteins prepared from marine bacteria Vibrio alginolyticus radiolabeled with ${ }^{3} \mathrm{H}$ - or ${ }^{14} \mathrm{C}$-leucine. Our data demonstrate that the proteins in crude membrane extract are degraded at much slower rate than the soluble proteins.

\section{MATERIALS AND METHODS}

Preparation of radiolabeled proteins in membrane and soluble fractions. To radiolabel bacterial proteins, Vibrio alginolyticus $138-2$ were grown on a glucose medium [glucose, $2 \mathrm{~g} ; \mathrm{NH}_{4} \mathrm{Cl}, 80 \mathrm{mg} \mathrm{K}_{2} \mathrm{HPO}_{4}, 10 \mathrm{mg}$; $\mathrm{FeCl}_{3} / 6 \mathrm{H}_{2} \mathrm{O}, 5 \mu \mathrm{g}$; and ASW (artificial seawater) $1 \mathrm{l}$; the composition of ASW as described by Samuelson \& Kirchman (1990)] which contained either ${ }^{3} \mathrm{H}$ - or ${ }^{14} \mathrm{C}$ leucine (NEN). Exponentially growing cells were harvested by centrifugation $(11950 \times g, 10 \mathrm{~min})$ and washed 3 times with ASW. Then the cells were disrupted by sonication ( $7 \mathrm{~W}, 5 \mathrm{~min}$ ), followed by ultracentrifugation $\left(55000 \times g, 1\right.$ h at $\left.4^{\circ} \mathrm{C}\right)$ to separate membrane (precipitates) and soluble (supernatant) fractions. The soluble fractions were further purified by using Centriprep-10 (Amjcon; $10 \mathrm{kD}$ cut off) to eliminate low-molecular-weight materials.

The precipitates resuspended in A.SW were used as a crude membrane preparation during an initial series of experiments (Expts 1, 2, and 3, see below). In this preparation, some intact bacteria, representing $<5 \%$ of total bacterial abundance before sonication, were found by the epifluorescence microscopy (Hobbie et al. 1977). In other experiments, we sonicated the crude membrane extract immediately before adding it to the samples (Expts 4 and 5) or treating it with Pronase $E$ (see below). After the second sonication, intact bacteria were not detected.
In one experiment, the crude membrane extract was further treated with proteases to eliminate proteins that loosely bind to membrane vesicles. The crude extract was added to the solution of Pronase E (Sigma; $500 \mathrm{mg} \mathrm{ml}^{-1}$ dissolved in ASW), incubated for $30 \mathrm{~min}$ at $22^{\circ} \mathrm{C}$. The protease-treated membrane fraction was then washed twice and collected by ultracentrifugation $(55000 \times g, 1 \mathrm{~h})$.

Biochemical characterization of radiolabeled preparations. To examine if proteins were specifically labeled by radiolabeled leucine, we measured the radioactivity in the hot trichloroacetic acid (TCA) soluble fraction and in the chloroform-soluble fraction of ${ }^{14} \mathrm{C}$. labeled membrane and soluble protein preparations. Samples were incubated with TCA (final conc. 5\%) at $100^{\circ} \mathrm{C}$ for 10 min. After centrifugation $\left(14000 \times g_{1}\right.$ $15 \mathrm{~min})$, the supernatant was radioassayed by liquid scintillation counting. The chloroform-soluble ${ }^{14} \mathrm{C}$ was determined after extraction with a lipid extraction mixture [chloroform:methanol:phosphate buffer $150 \mathrm{mM}$, $\mathrm{pH} 7.4)=1: 2: 0.8$ ] followed by phase separation by an addition of chloroform and the buffer (Nagata \& Kirchman 1992).

We also examined the hydrolysis of radiolabeled proteins by proteases. Samples were incubated with the protease, Pronase $\mathrm{E}\left(1 \mathrm{mg} \mathrm{ml} \mathrm{m}^{-1}\right.$ in $\left.\mathrm{ASW}\right)$ at $22^{\circ} \mathrm{C}$ for $2.5 \mathrm{~h}$ after which TCA (final conc. $5 \%$ ) and bovine serum albumin (BSA) carrier (final conc $1 \mathrm{mg} \mathrm{m}^{-1}$ ) were added to the sample. Precipitated proteins were centrifuged $(14000 \times g, 15 \mathrm{~min})$ and the supernatant was radioassayed.

The protein concentration in each preparation was determined by the Bradford method (BioRad) with BSA as a standard. Specific activities (radioactivity per $\mathrm{mg}$ of proteins) of ${ }^{3} \mathrm{H}$ and ${ }^{14} \mathrm{C}$ preparations were 103000 to

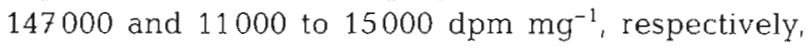
which varied depending on the batches.

Degradation of proteins by natural bacterioplankton. Surface water samples were collected from estuarine (Delaware Bay, USA) or coastal (U.S. Atlantic coast) environments. The location and date of sample collection and concentrations of added proteins (28 to $7800 \mathrm{Hg} \mathrm{l}^{-1}$ ) are presented in Table 1.

Single-label experiments: in Expts 1, 2 and 3, we used ${ }^{14} \mathrm{C}$-labeled membrane and ${ }^{14} \mathrm{C}$-labeled soluble fractions (Table 1). In these experiments, either membrane or soluble fraction was added to $10 \mathrm{ml}$ of $0.8 \mu \mathrm{m}$ prefiltered sample water and incubated in glass vials. The vials were incubated in the dark at $22^{\circ} \mathrm{C}$. Duplicate vials were used to determine accumulation of ${ }^{14} \mathrm{CO}_{2}$ in seawater. A subsample $(1 \mathrm{ml}$ ) from each vial was acidified and the released ${ }^{14} \mathrm{CO}_{2}$ was trapped with ethanolamine (Hobbie \& Crawford 1969). Radioactivity was assayed by liquid scintillation counting. In Expts 2 and 3 , we determined ${ }^{14} \mathrm{C}$ in low-molecular-weight dis- 
Table 1. Sampling locations and concentrations of added proteins

\begin{tabular}{|c|c|c|c|}
\hline Expt & $\begin{array}{l}\text { Location } \\
\text { (date of sampling) }\end{array}$ & $\begin{array}{l}\text { Preparation } \\
\text { (label/protein) }\end{array}$ & $\begin{array}{c}\text { Added conc } \\
\left(\mu \mathrm{g} \mathrm{l}^{-1}\right)\end{array}$ \\
\hline 1 & $\begin{array}{l}\text { Delaware Bay, } \\
\text { Roosevelt Inlet } \\
(2 \text { Oct 1994) }\end{array}$ & $\begin{array}{l}{ }^{14} \mathrm{C} / \text { membrane } \\
{ }^{14} \mathrm{C} / \text { soluble }\end{array}$ & $\begin{array}{l}3600 \\
3000\end{array}$ \\
\hline 2 & $\begin{array}{l}\text { Atlantic coast, } \\
\text { Indian River Inlet } \\
\text { (5 Oct 1994) }\end{array}$ & $\begin{array}{l}{ }^{14} \mathrm{C} / \text { membrane } \\
{ }^{14} \mathrm{C} / \text { soluble }\end{array}$ & $\begin{array}{l}7500 \\
6900\end{array}$ \\
\hline 3 & $\begin{array}{l}\text { Delaware Bay, } \\
\text { Roosevelt Inlet } \\
(5 \text { Oct } 1994)\end{array}$ & $\begin{array}{l}{ }^{14} \mathrm{C} / \text { membrane } \\
{ }^{14} \mathrm{C} \text { /soluble }\end{array}$ & $\begin{array}{l}7800 \\
7300\end{array}$ \\
\hline 4 & $\begin{array}{l}\text { The middle of } \\
\text { Delaware Bay } \\
\text { (6 Sep 1995) }\end{array}$ & $\begin{array}{l}{ }^{3} \mathrm{H} / \text { membrane } \\
{ }^{14} \mathrm{C} / \text { soluble }\end{array}$ & $\begin{array}{l}100 \\
840\end{array}$ \\
\hline 5 & $\begin{array}{l}\text { Atlantic coast, } \\
\text { Indian River Inlet } \\
\text { (9 Sep 1996) }\end{array}$ & $\begin{array}{l}{ }^{3} \mathrm{H} / \text { membrane } \\
{ }^{14} \mathrm{C} / \text { soluble }\end{array}$ & $\begin{array}{l}35 \\
28\end{array}$ \\
\hline
\end{tabular}

solved organic matter (LMW-DOM). TCA (final conc. $5 \%$ ) and protein carrier (BSA, final conc. $1 \mathrm{mg} \mathrm{m}^{-1}$ ) were added to the samples. After incubation (10 to $15 \mathrm{~min}$ ), precipitated proteins were collected by centrifugation (14000 $\times \mathrm{g}$, for $15 \mathrm{~min})$, and radioactivity in the supernatant was assayed by liquid scintillation counting. In this series of experiments, we did not determine ${ }^{14} \mathrm{CO}_{2}$ in the head space of incubation vials. Release of ${ }^{14} \mathrm{CO}_{2}$ to the head space, if any, would result in underestimation of the degradation rates, but should not affect our comparison of degradation rates of membrane and soluble proteins.

Dual-label experiments: in Expts 4 and 5, mixtures of ${ }^{14} \mathrm{C}$-soluble and ${ }^{3} \mathrm{H}$-membrane fractions were added to $20 \mathrm{ml}$ of $0.8 \mu \mathrm{m}$ - (Expt 4 ) or $0.6 \mu \mathrm{m}$-prefiltered (Expt 5) seawater contained in glass vials sealed with teflonlined rubber septum caps. To minimize the leakage of ${ }^{14} \mathrm{CO}_{2}$, the addition of chemicals and the purging of ${ }^{14} \mathrm{CO}_{2}$ (see below) were conducted by using needles penetrating through the rubber septum. The vials were incubated in the dark at $22^{\circ} \mathrm{C}$. At each sampling time, duplicate vials were fixed with neutralized Formalin (final conc. $2 \%$ ) for the later analysis of ${ }^{14} \mathrm{CO}_{2}$ (see below). Another set of 2 vials was used for determining abundances of bacteria and flagellates (acridine orange direct count method; Hobbie et al. 1977), and ${ }^{3} \mathrm{H}$ activities in LMW material (TCA-soluble fraction, see above).

To measure ${ }^{14} \mathrm{CO}_{2}$, the sample was acidified with $\mathrm{H}_{2} \mathrm{SO}_{4}$ and bubbled with air or nitrogen gas (>20 min). The purged ${ }^{14} \mathrm{CO}_{2}$ was trapped in 2 sequentially con- nected $20 \mathrm{ml}$ vials, each of which contained $10 \mathrm{ml}$ of scintillation cocktail formulated to absorb ${ }^{14} \mathrm{CO}_{2}$ (toluene, $1500 \mathrm{ml}$; methanol, $1200 \mathrm{ml}_{i}$ ethanolamine, $300 \mathrm{ml}$; 1,5-bis(5')-tert-butylbenzoxazolyl-[2']thiophene, $6 \mathrm{~g}$; Moran \& Hodson 1989]. Radioactivity was measured by liquid scintillation counting. The isotope recovery determined by using seawater samples amended with a known amount of ${ }^{14} \mathrm{CO}_{2}$ was $>98 \%$. Degradation rates of proteins were determined as increases in ${ }^{14} \mathrm{CO}_{2}$ or ${ }^{3} \mathrm{H}$-LMW material over time.

In order to examine if ${ }^{3} \mathrm{H}$-LMW material is produced abiotically during the incubation, ${ }^{3} \mathrm{H}$-labeled membrane fraction was incubated in seawater to which either Formalin (final conc. $2 \%$ ) or sodium azide (final conc. $0.5 \%$ ) was added. ${ }^{3} \mathrm{H}$ in the LMW fraction was determined (see above) before and after the incubation for $7 \mathrm{~d}$.

\section{RESULTS}

\section{Biochemical characterization of radiolabeled protein preparations}

Cultures of Vibrio alginolyticus were grown with radiolabeled leucine and the protein was harvested for use in degradation experiments. To examine if radiolabeled leucine was specifically incorporated into proteins, we determined the radioactivity in hot-TCAsoluble and in chloroform-soluble fractions of the ${ }^{14} \mathrm{C}$-labeled protein preparations. We found that, of total ${ }^{14} \mathrm{C}$ in soluble and membrane preparations, $<1 \%$ was in the hot-TCA-soluble fraction and $<5 \%$ in the chloroform-soluble fraction while most of the radioactivity (>95\%) was in the protein fraction as expected. These results indicate that non-specific radiolabeling of nonproteinous macromolecules including nucleic acids and phospholipids was minimal.

Susceptibility of proteins to Pronase E hydrolysis differed between soluble and membrane preparations (Table 2). Radiolabeled proteins in the soluble fraction were mostly (>92\%) hydrolyzed by Pronase E,

Table 2. Percentage of proteins hydrolyzed by Pronase $\mathrm{E}$ $\left(1 \mathrm{mg} \mathrm{ml}^{-1}\right.$ in ASW). Samples were incubated for $2.5 \mathrm{~h}$ at $20^{\circ} \mathrm{C}$

\begin{tabular}{|c|c|}
\hline $\begin{array}{l}\text { Preparation } \\
\text { (label/protein) }\end{array}$ & $\begin{array}{l}\% \text { hydrolyzed } \pm \mathrm{SD} \\
\quad(\mathrm{n}=2)\end{array}$ \\
\hline${ }^{3} \mathrm{H} /$ soluble & $92 \pm 3$ \\
\hline${ }^{14} \mathrm{C} /$ soluble & $96 \pm 13$ \\
\hline${ }^{3} \mathrm{H} /$ membrane & $65 \pm 1$ \\
\hline${ }^{14} \mathrm{C} /$ membrane & $58 \pm 10$ \\
\hline${ }^{3} \mathrm{H} /$ membrane (Pronase E pretreated) ${ }^{\mathrm{a}}$ & $3 \pm 1$ \\
\hline \multicolumn{2}{|c|}{$\begin{array}{l}{ }^{\mathrm{d}} \text { Crude membrane extract was pretreated with Pronase } \mathrm{E} \\
\text { to eliminate proteins loosely bound to membrane vesicles }\end{array}$} \\
\hline
\end{tabular}



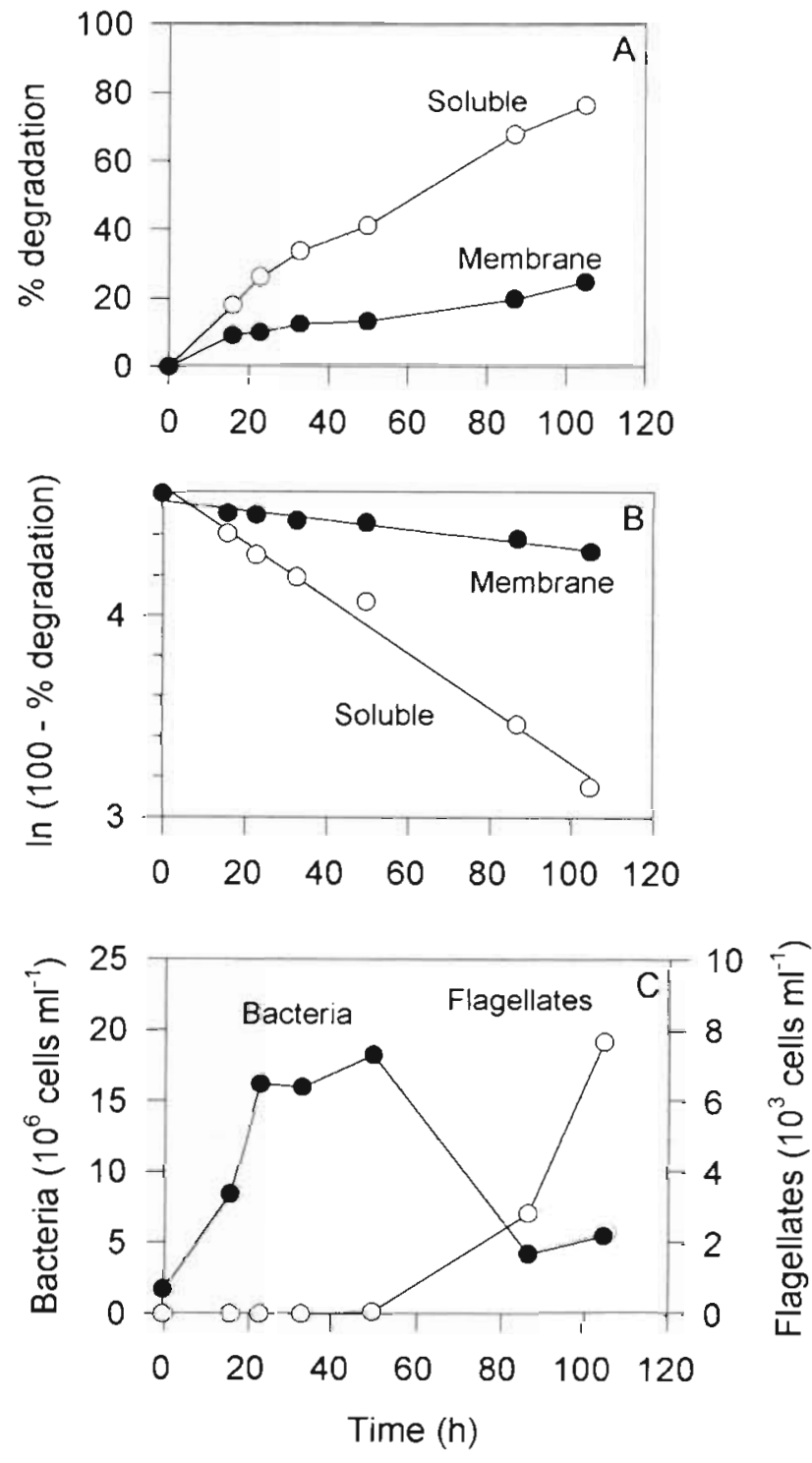

Fig 1 Time course of the degradation of ${ }^{3} \mathrm{H}$-labeled membrane (Membrane) and ${ }^{14} \mathrm{C}$-labeled soluble (Soluble) proteins in seawater (Expt 4). (A) \% of protein degraded relative to amount of protein added. (B) Natural-log transformed plot of (100 - \% degradation) for the first order kinetic analysis.

(C) Abundance of bacteria and flagellates

whereas a signifirant fraction of proteins in the membrane fraction $\left(35 \%\right.$ in ${ }^{3} \mathrm{H}$ and $42 \%$ in ${ }^{14} \mathrm{C}$ preparations) was resistant to the Pronase $\mathrm{E}$ hydrolysis.

\section{Microbial dynamics and protein degradation}

Fig. 1 represents the data from Expt 4 as an example of the time course of protein degradation and changes in microbial abundances. Bacterial abundance increased during the first $20 \mathrm{~h}$ to reach the maximum level $\left(1.5 \times 10^{7}\right.$ cells $\left.\mathrm{ml}^{-1}\right)$. After $50 \mathrm{~h}$, bacterial abundance decreased while flagellate abundance increased. The flagellate abundance was as high as $8 \times$ $10^{3}$ cells $\mathrm{ml}^{-1}$. A similar general pattern of changes in abundance of bacteria and flagellates was observed in Expt 5 (data not shown). No data of microbial abundances are available for Expts 1, 2, and 3

The time course of protein degradation was described well by a model of first-order kinetics during the entire incubation period in Expt 4 (Fig. 1B) and other experiments, except that a lag period was observed during the initial $6 \mathrm{~h}$ in Expt 1 (data not shown). When degradation was linear, the $\mathrm{r}^{2}$ for the linear regression of $\ln (100-\%$ degradation $)$ against time was 0.95 to 0.99 (Fig. 1B, Table 3). It is notable that degradation rates of soluble and membrane proteins did not change substantially after rapid growth of flagellates at the latter stage of incubation (Fig. 1C). This result suggests that ingestion of proteins by flagellates (Tranvik et al. 1993) contributed little to the degradation of proteins in our experiments.

Degradation rate constants varied in the range of 0.0023 to 0.0050 and 0.0086 to $0.0136 \mathrm{~h}^{-1}$ for the membrane and soluble fractions, respectively (Table 3). Comparisons (analysis of covariance) of the rate constant between membrane and soluble fractions indicated that the degradation rate of proteins in the membrane fraction was significantly $(p<0.05)$ lower than that of proteins in the soluble fraction in all the experiments; turnover rates of soluble proteins were 2 - to 6 -fold greater than those of membrane proteins in seawater (Table 3 ).

We determined changes in LMW-DOM radioactivity over the time in Expts 2 and 3. Results indicated that LMW-DOM did not accumulate significantly; of total ${ }^{14} \mathrm{C}$ added, $<5 \%$ of the radioactivity was detected in the LMW-DOM during the entire incubation periods for both soluble and membrane fractions, suggesting that hydrolysis rather than uptake was the limiting step of protein degradation.

\section{Degradation of membrane fraction pretreated with Pronase E}

Proteins in membrane fractions probably consist of 2 components: proteins loosely bound to membrane vesicles, and those embedded in or trapped inside membrane vesicles. We hypothesized that embedded proteins are less easily degraded than loosely bound proteins because of protection by cell wall and membrane materials. To examine this possibility, we determined degradation of ${ }^{3} \mathrm{H}$-labeled proteins in membrane fractions pretreated with Pronase E, a treatment which may eliminate loosely bound proteins. Of total 
Table 3. Comparisons of degradation rate constant between membrane (Mem) and soluble (Sol) proteins

\begin{tabular}{|c|c|c|c|c|c|c|}
\hline $\operatorname{Expt}^{\lrcorner}$ & $\begin{array}{l}\text { Period } \\
\text { (h) }\end{array}$ & $\mathrm{n}$ & \multicolumn{2}{|c|}{ Degradation rate constant $t^{b} \pm S E\left(\mathrm{~h}^{-1}\right)$} & $p^{c}$ & $\mathrm{Sol} / \mathrm{Mem}^{\mathrm{d}}$ \\
\hline 1 & $6-41$ & 4 & $0.0035 \pm 0.0004$ & $0.0103 \pm 0.0012$ & $<0.01$ & 3.0 \\
\hline 2 & $0-48$ & 5 & $0.0030 \pm 0.0003$ & $0.0095 \pm 0.0022$ & $<0.05$ & 2.9 \\
\hline 3 & $0-48$ & 5 & $0.0034 \pm 0.0005$ & $0.0102 \pm 0.0014$ & $<0.005$ & 3.0 \\
\hline 4 & $0-105$ & 7 & $0.0023 \pm 0.0003$ & $0.0136 \pm 0.0006$ & $<0.001$ & 5.8 \\
\hline 5 & $0-224$ & 7 & $0.0050 \pm 0.0003$ & $0.0086 \pm 0.0009$ & $<0.005$ & 1.7 \\
\hline \multicolumn{7}{|c|}{$\begin{array}{l}{ }^{a} \text { See Table } 1 \text { for description of the various experiments } \\
\text { b The first order kinetic constant was calculated as a slope of the linear regression between } \ln (100-\% \text { degradation) and time } \\
{ }^{c} \text { Null hypothesis: difference of degradation rate constant between }{ }^{3} \mathrm{H} \text {-labeled membrane and }{ }^{14} \mathrm{C} \text {-labeled soluble proteins } \\
{ }^{0} \text {; tested by analysis of covariance ( } 2 \text {-tailed) } \\
{ }^{\mathrm{d}} \text { Ratio of rate constants for soluble to membrane proteins }\end{array}$} \\
\hline
\end{tabular}

${ }^{3} \mathrm{H}$-labeled proteins in the crude membrane extract, $45 \%$ was not degraded by the Pronase E treatment.

We found that ${ }^{3} \mathrm{H}$-labeled proteins in the pretreated membranes were not degraded during the initial $45 \mathrm{~h}$, whereas a substantial fraction $(24 \%)$ of ${ }^{14} \mathrm{C}$-labeled soluble proteins was degraded during the same period (Fig. 2, Table 4). This result is consistent with our hypothesis that membrane and wall materials severely restricted access of bacterial proteases to membrane proteins. However, after $45 \mathrm{~h},{ }^{3} \mathrm{H}$-labeled proteins in the pretreated membrane fraction started to be degraded with a rate constant of $0.0040 \pm 0.0005 \mathrm{~h}^{-1}$ $( \pm \mathrm{SE}, \mathrm{n}=5$; Table 4$)$. The rate constant of ${ }^{14} \mathrm{C}$-labeled soluble proteins during the same period was $0.0146 \pm$ $0.0013 h^{-1}$, which was 3.7 -fold greater $(p<0.001)$ than that of membrane proteins (Table 4). At the end of the

Table 4. Degradation rate constants for ${ }^{3} \mathrm{H}-$-labeled membrane (Mem) (pretreated with Pronase E) and ${ }^{14} \mathrm{C}$-labeled soluble (Sol) proteins. Added concentrations of proteins were 32 and $21 \mathrm{\mu g}^{-1}$ for membrane and soluble proteins, respectively. The seawater sample used for the incubation was the same as in Expt 5 (see Table 1)

\begin{tabular}{|c|c|c|c|c|}
\hline $\begin{array}{l}\text { Period } \\
\text { (h) }\end{array}$ & $\mathrm{n}$ & $\begin{array}{l}\text { Degradation ra } \\
{ }^{3} \mathrm{H} \text { membrane }\end{array}$ & $\begin{array}{l}\text { constant }\left(\mathrm{h}^{-1}\right) \\
{ }^{14} \mathrm{C} \text { soluble }\end{array}$ & $\mathrm{Sol} \mathrm{Mem}^{\mathrm{a}}$ \\
\hline $0-45$ & 3 & $<0.0004^{b}$ & $\begin{array}{c}0.0056 \\
\pm 0.0020\end{array}$ & $>14$ \\
\hline $45-224$ & 5 & $\begin{array}{c}0.0040 \\
\pm 0.0005\end{array}$ & $\begin{array}{c}0.0146 \\
\pm 0.0013\end{array}$ & $3.7^{c}$ \\
\hline \multicolumn{5}{|c|}{$\begin{array}{l}\text { "Ratio of rate constants for soluble to membrane proteins } \\
\text { 'The degradation rate was below the detection limit which } \\
\text { was defined as a rate at which the LMW-DOC radioactiv- } \\
\text { ity after } 45 \mathrm{~h} \text { is within } 20 \% \text { of the corresponding time } \\
\text { zero value } \\
\text { 'Null hypothesis: difference of degradation rate constant } \\
\text { between }{ }^{3} \mathrm{H} \text {-labeled membrane and }{ }^{14} \mathrm{C} \text {-labeled soluble } \\
\text { proteins }=0 \text {; rejected }(\mathrm{p}<0.001) \text { by analysis of covariance } \\
(2 \text {-tailed) }\end{array}$} \\
\hline
\end{tabular}

incubation ( $224 \mathrm{~h}$ ), $48 \%$ of ${ }^{3} \mathrm{H}$-labeled proteins initially present in the membrane fraction was degraded (Fig. 2).
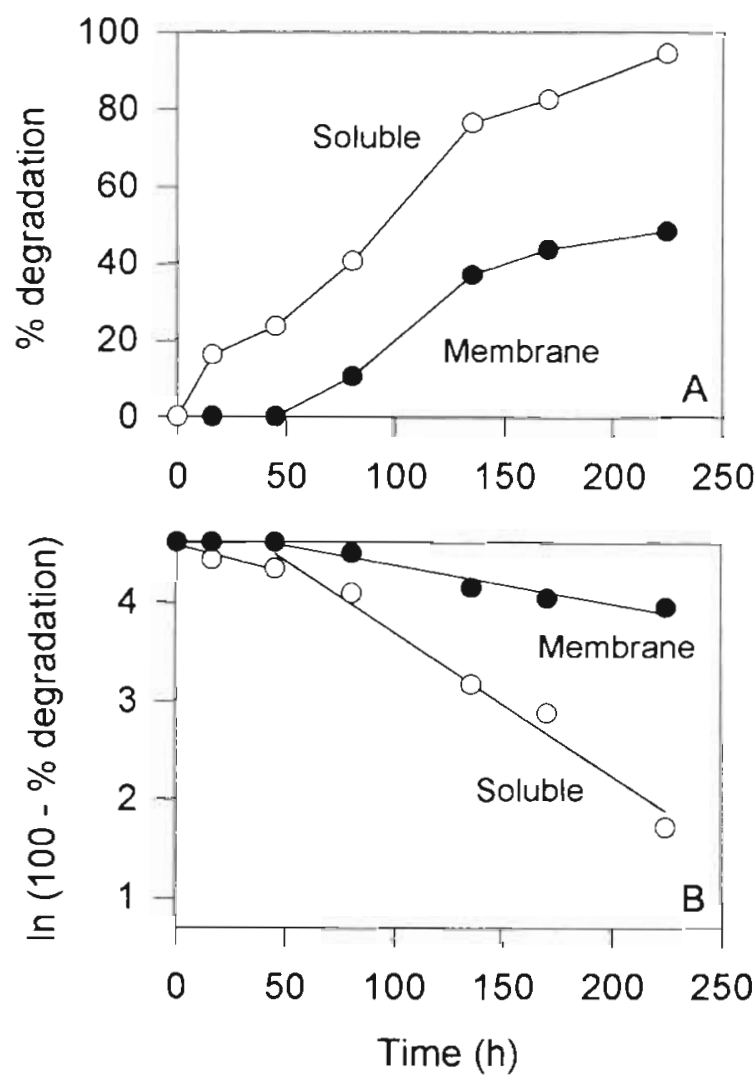

Fig. 2. Time course of the degradation of ${ }^{3} \mathrm{H}$-labeled membrane (Membrane) and ${ }^{14} \mathrm{C}$-labeled soluble (Soluble) proteins in seawater. The membrane fraction was pretreated with Pronase $E$ in order to eliminate proteins loosely bound to membrane vesicles. Note that degradation of protein was not detected in the membrane fraction during the initial $45 \mathrm{~h}$. (A) $\%$ of protein degraded relative to amount of protein added. (B) Natural-log transformed plot of $(100-\%$ degradation) for the first order kinetic analysis 

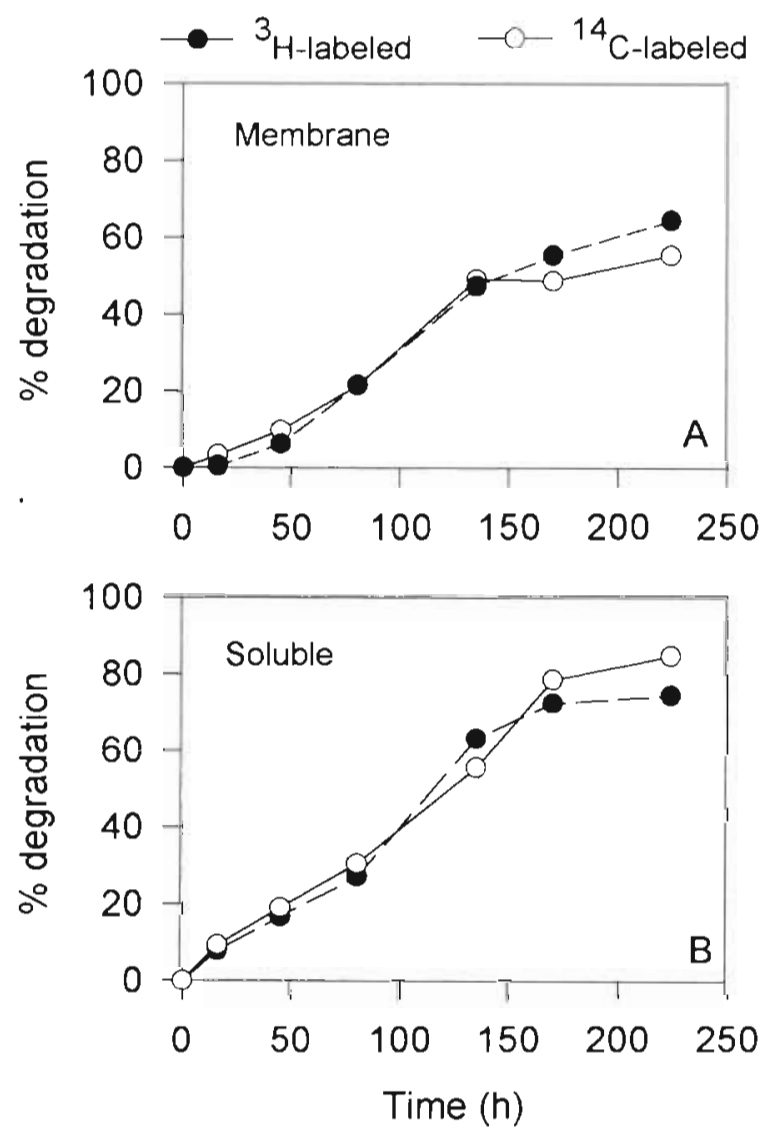

Fig. 3. Comparison of the degradation of proteins between ${ }^{14} \mathrm{C}$-labeled and ${ }^{3} \mathrm{H}$-labeled preparations of (A) membrane and $(B)$ soluble proteins

\section{Effect of ${ }^{14} \mathrm{C}$ - and ${ }^{3} \mathrm{H}$-labeling on measurement of protein degradation}

To examine if the method of radiolabeling $\left({ }^{14} \mathrm{C}\right.$ - vs ${ }^{3} \mathrm{H}$-labeling) or the method of detecting degradation $\left({ }^{14} \mathrm{CO}_{2}\right.$ vs ${ }^{3} \mathrm{H}$-LMW material) affected our estimation of degradation rates in dual-label experiments (Expts 4 and 5), we conducted an experiment in parallel with Expt 5, in which we used ${ }^{3} \mathrm{H}$-labeled soluble and ${ }^{14} \mathrm{C}$ labeled membrane fractions rather than ${ }^{14} \mathrm{C}$-soluble and ${ }^{3} \mathrm{H}$-membrane fractions. Added protein concentrations of membrane and soluble fractions were the same as Expt 5 (Table 1). The time course of the \% degradation (degraded protein/total protein added) differed litthe between ${ }^{14} \mathrm{C}$ - and ${ }^{3} \mathrm{H}$-labeled preparations (Fig. 3). Also, first order kinetic constants for ${ }^{14} \mathrm{C}$ - and ${ }^{3} \mathrm{H}$ labeled preparations did not differ significantly $(p>$ 0.05) (Table 5). These results indicate that the differences in degradation rates between ${ }^{14} \mathrm{C}$-labeled soluble and ${ }^{3} \mathrm{H}$-labeled membrane proteins observed in Expts 4 and 5 (Fig. 1A, B, Table 3) were not due to the difference in the method of radiolabeling.
Table 5. Comparisons of the first order kinetic degradation constant between ${ }^{3} \mathrm{H}$ - and ${ }^{14} \mathrm{C}$-labeled bacterial proteins

\begin{tabular}{|c|c|c|c|}
\hline \multirow[t]{2}{*}{ Fraction } & \multicolumn{2}{|c|}{ Degradation rate constant $\left(\mathrm{h}^{-1}\right)$} & \multirow[t]{2}{*}{$p^{d}$} \\
\hline & ${ }^{14} \mathrm{C}$-labeled & ${ }^{3} \mathrm{H}$-labeled & \\
\hline Soluble & $0.0086 \pm 0.0009$ & $0.0068 \pm 0.0007$ & $>0.10$ \\
\hline Membrane & $0.0040 \pm 0.0004$ & $0.0050 \pm 0.0003$ & $>0.05$ \\
\hline \multicolumn{4}{|c|}{$\begin{array}{l}\text { Null hypothesis: difference of the degradation rate } \\
\text { constant between }{ }^{3} \mathrm{H} \text { - and }{ }^{14} \mathrm{C} \text {-labeled preparations }=0 \\
\text { tested by analysis of covariance ( } 2 \text {-tailed). } \mathrm{n}=7 \text { for both } \\
\text { soluble and membrane fractions }\end{array}$} \\
\hline
\end{tabular}

\section{Recovery of proteins during incubation}

In order to examine if membrane and soluble proteins adsorb to the wall of incubation vials, we measured total ${ }^{3} \mathrm{H}$ in sample water over time in Expt $5\left({ }^{3} \mathrm{H}\right.$ labeled membrane protein; Tables $1 \& 3$ ) and in other experiments in which ${ }^{3} \mathrm{H}$-labeled soluble protein (Fig. 3, Table 5) or ${ }^{3} \mathrm{H}$-labeled membrane protein pretreated with Pronase E (Fig. 2, Table 4) were used. We found that during the latter period of the incubation (135 to $224 \mathrm{~h})$, total ${ }^{3} \mathrm{H}$ recovered in the sample water was $108 \pm 4 \%\left({ }^{3} \mathrm{H}\right.$-labeled membrane; average $\pm \mathrm{SD}$, $\mathrm{n}=3), 117 \pm 10 \%\left({ }^{3} \mathrm{H}\right.$-labeled soluble $)$ or $91 \pm 5 \%\left({ }^{3} \mathrm{H}\right.$ membrane pretreated with Pronase E), respectively, of total ${ }^{3} \mathrm{H}$ initially added. This result indicates that the slower degradation rate of membrane proteins relative to soluble proteins cannot be explained by differential adsorption of proteins to the wall of incubation vials.

\section{Abiotic production of ${ }^{3} \mathrm{H}-\mathrm{LMW}$ material}

To examine if ${ }^{3} \mathrm{H}$-LMW material is produced abiotically, the ${ }^{3} \mathrm{H}$-labeled membrane preparation was incubated in seawater to which Formalin or sodium azide was added. We found that in the killed controls, only $<0.05 \%$ of total ${ }^{3} \mathrm{H}$ initially added was recovered in the LMW fraction after $7 \mathrm{~d}$ of incubation. Thus we conclude that the accumulation of ${ }^{3} \mathrm{H}$-LMW material that we observed in our experiments was mostly due to microbial processes rather than abiotic processes.

\section{DISCUSSION}

Previous studies have examined degradation by bacteria of soluble proteins in seawater by using fluorescent analogs (e.g. leucine-4-methylcoumarinyl-7amide$_{i}$ Hoppe 1993) and purified proteins (e.g. ${ }^{14} \mathrm{C}$-methylated BSA; Hollibaugh \& Azam 1983). Although these model substrates are useful in deter- 
mining potential degradation rates of soluble proteins (Billen 1991, Chróst 1991), they do not adequately model the complexity of protein mixtures, such as complexes with other components dissolved in natural seawater (Nagata \& Kirchman 1997). Recent research has suggested that association of proteins with other organic compounds may affect greatly degradability of proteins in seawater (Keil \& Kirchman 1994, Nagata \& Kirchman 1996). In the present study, we used bacterial membrane proteins as a model for macromolecular organic complexes in seawater. Comparisons of the degradation rate between 2 distinctive protein components, i.e. membrane and soluble proteins, allow us to discuss some mechanistic bases for the variability in turnover rates among different components of dissolved organic matter in seawater. Note that membrane proteins would not be truly 'dissolved' in a chemical sense, but are small particles that pass through filters (typical nominal retention 0.4 to $0.7 \mu \mathrm{m}$ ) which are used to define 'dissolved components' in oceanography (Nagata \& Kirchman 1997).

Our data indicate that proteins associated with bacterial membranes are less easily degraded than soluble proteins derived from the same bacteria. First order kinetic degradation constants for membrane proteins were significantly lower $(1 / 2$ to $1 / 6)$ than those of soluble proteins (Table 3 ) over a wide range of added concentrations (28 to $7800 \mathrm{\mu g} \mathrm{l}^{-1}$; Table 1 ). These results are consistent with the hypothesis that membrane proteins are protected from rapid enzymatic attack by bacteria because of tight association of proteins with membrane and wall materials. Gram negative bacterial membranes and walls consist of phospholipids, peptidoglycan and lipopolysaccharide, which complex with membrane proteins by electrostatic and hydrophobic interactions (Nikaido \& Vaara 1985, Weiss et al. 1991). After disruption of bacterial cells by sonication, membrane and wall fragments may form liposomes (membrane vesicles with aqueous phase inside; New 1990) in which proteins are embedded or trapped. Also some soluble proteins may adsorb to the surfaces of these vesicles. Consistent with this model, we found that 35 to $42 \%$ of ${ }^{3} \mathrm{H}$ - and ${ }^{14} \mathrm{C}$-labeled protein in membrane fractions was not hydrolyzed by Pronase E, whereas 92 to $96 \%$ of soluble protein was hydrolyzed (Table 2), suggesting that more than one-third of protein in the membrane fraction was either embedded in lipids and wall layers or was trapped inside the liposomes.

We cannot totally exclude the possibility that some proteins in the membrane fraction were resistant to protease hydrolysis because of inherent structural properties of the proteins rather than complexation of the proteins with other macromolecules. However, early work with Escherichia coli (Rosenbusch 1974) and our own results with Vibrio alginolyticus ( $R$.
Fukuda unpubl.) have found that outer membrane proteins are mostly degraded by proteases after extraction from other membrane components, suggesting that organic matter interactions play a major role in resistance of membrane proteins to proteolysis.

Degradation of membrane proteins by marine bacterial assemblages may be inhibited because bacterial proteases cannot gain access to proteins shielded by membrane and wall components. In support of this, our results demonstrated that degradation of protein in the membrane fraction pretreated with Pronase $E$ was totally inhibited during the initial $45 \mathrm{~h}$ of incubation (Fig. 2, Table 4). Rapid degradation of soluble proteins during the same period (Fig. 2, Table 4) indicates that bacterial proteases were active, but these proteases could not degrade proteins associated with membrane materials. During this period, turnover rate of membrane protein was below the detection limit of our assay $\left(<0.0004 \mathrm{~h}^{-1}\right)$ and was at least 14 -fold lower than that of soluble proteins (Table 4 ).

However, after prolonged incubation (>45 h), membrane proteins started to be degraded. At the end of the incubation $(224 \mathrm{~h})$, the fraction of degraded protein relative to the total amount added was $48 \%$, a value which was much higher than the percentage of protein which was hydrolyzable by Pronase E ( $3 \%$; Table 2). Our interpretation of this result is that proteins originally protected by membrane components were made available for proteolytic degradation because ectoenzymes produced by bacterioplankton destroyed the membrane components. Although we know very little about degradation of phospholipids, peptidoglycan and lipopolysaccharide in seawater, recent studies using fluorescent analogs have indicated that marine bacterial isolates (Martinez et al. 1996) and natural bacterial assemblages (Smith et al. 1992, Martinez et al. 1996) exhibit activities of various ectoenzymes including phospholipase and lysozyme. Thus, our data support the idea that complementary hydrolysis by different ectoenzymes could facilitate degradation of macromolecular organic complexes in seawater (Martinez et al. 1996).

One factor that may affect the degradation rate of proteins associated with membrane vesicles is the collision frequency between these vesicles and bacteria. Nagata \& Kirchman (1996) found that the degradation rate of proteins adsorbed to model submicron particles (latex beads) varied depending on the size of particles (size range 0.1 to $1.5 \mu \mathrm{m}$ ). The degradation rates were explained in part by size-dependent probability of collision between submicron particles and bacteria (Johnson \& Kepkay 1992). In our study, we did not examine the size distribution and number of membrane vesicles, so collision frequencies could not be calculated. The collision theory would in part explain the differ- 
ence in degradation between the membrane and soluble proteins, particularly when the protein concentration was low. However, membrane proteins were degraded at slower rates than soluble proteins even when the added protein concentration was high (3000 to $7800 \mu \mathrm{gl}^{-1}$ in Expts 1, 2 and 3). At these high concentrations, which are much higher than the typical concentration of DCAA in coastal and estuarine environments (100 to $1000 \mu \mathrm{g} \mathrm{I}^{-1}$ i Keil \& Kirchman 1993), it is unlikely that bacterial hydrolysis of proteins was limited by transport (collision). Furthermore, the degradation rate of soluble proteins relative to that of membrane proteins (1.7 to 5.8; Table 3 ) did not covary with added protein concentration (35 to 7800 and 28 to $7300 \mu \mathrm{g} \mathrm{l}^{-1}$ for membrane and soluble proteins; Table 1). Based on the above results, we suggest that hydrolytic reactions rather than transport processes were more important in determining the degradation of membrane proteins in our experiments.

In summary, our results suggest that bacterial membrane proteins resist bacterial degradation due to steric protection of the proteins by membrane and wall components. These results probably explain in part selective accumulation of porin molecules in oceanic waters (Tanoue et al. 1995, 1996). More generally, membrane and soluble proteins should be degraded differently regardless of the source of the protein, which implies that our results should apply to dissolved proteins released by phytoplankton and heterotrophic protists along with sloppy feeding, viral infection and other mortality processes. Because proteins bound to membranes account for a large fraction (20 to 60\%; Alberts et al. 1994) of total proteins of cells the total amount of membrane proteins that are channelled through the 'dissolved' protein pool in seawater could be substantial. Because of the slow turnover and close association of proteins with other macromolecules including polysaccharides, membrane proteins probably have more chances to be modified geochemically, which may result in the formation of refractory proteins (Hedges 1988, Yamamoto \& Ishiwatari 1989, Keil \& Kirchman 1994). Thus structures of macromolecular organic complexes and their interactions with marine bacterial assemblages could substantially influence stordye, turnover and transport of dissolved organic matter in the oceans.

Acknowledgements. We thank N. Borch for suggestions and technical help. This study was supported by grants from MESSC and NSF

\section{LITERATURE CITED}

Alberts B, Bray D, Lewes J, Raff $M$, Roberts $K$, Watson JD (1994) Molecular biology of the cell, 3rd edn. Garland Publishing, New York
Billen G (1991) Protein degradation in aquatıc environments. In: Chróst RJ (ed) Microbial enzymes in aquatic environments. Springer-Verlag, New York, p 123-143

Chróst RJ (1991) Environmental control of the synthesis and activity of aquatic microbial ectoenzymes. In: Chróst RJ (ed) Microbial enzymes in aquatic environments. Springer-Verlag, New York, p 29-59

Coffin RB (1989) Bacterial uptake of dissolved free and combined amino acids in estuarine waters. Limnol Oceanogr $34: 531-542$

Hedges JI (1988) Polymerization of humic substances in natural environments. In: Frimmel FH, Christman RF (eds) Humic substances and their role in the environment. John Wiley \& Sons, New York, p 45-58

Hobbie JE, Crawford CC (1969) Respiration corrections for bacterial uptake of dissolved organic compounds in natural waters. Limnol Oceanogr 14:528-532

Hobbie JE, Daley RJ, Jasper S (1977) Use of Nuclepore filters for counting bacteria by fluorescence microscopy. Appl Environ Microbiol 33:1225-1228

Hollibaugh JT, Azam F (1983) Microbial degradation of dissolved proteins in seawater. Limnol Oceanogr 28 : $1104-1116$

Hoppe HG (1993) Use of fluorogenic model substrates for extracellular enzyme activity (EEA) measurement of bacteria. In: Kemp PF, Sherr BF, Sherr EB, Cole JJ (eds) Handbook of methods in aquatic microbial ecology. Lewis Publishers, Boca Raton, p 423-431

Johnson BD, Kepkay PE (1992) Colloid transport and bacterial utilization of oceanic DOC. Deep Sea Res 39:855-869

Keil RG, Kirchman DL (1993) Dissolved combined amino acids: chemical form and utilization by marine bacteria. Limnol Oceanogr 38:1256-1270

Keil RG, Kirchman DL (1994) Abiotic transformation of labile protein to refractory protein in seawater. Mar Chem 45 : $187-196$

Martinez J, Smith DC, Steward GF, Azam F (1996) Variability in ectohydrolytic enzyme activities of pelagic marine bacteria and its significance for substrate processing in the sea. Aquat Microb Ecol 10:223-230

Moran MA, Hodson RE (1989) Formation and bacterial utilization of dissolved organic carbon derived from detrital lignocellulose. Limnol Oceanogr 34:1034-1047

Nagata T, Kirchman DL (1992) Release of macromolecular organic complexes by heterotrophic marine flagellates. Mar Ecol Prog Ser 83:233-240

Nagata T, Kirchman DL (1996) Bacterial degradation of protein adsorbed to model submicron particles in seawater. Mar Ecol Prog Ser 132:241-248

Nagata T, Kirchman DL (1997) Roles of submicron particles and colloids in microbial food webs and biogeochemical cycles within marine environments. Adv Microb Ecol 15 (in press)

New RRC (1990) Liposomes - a practical approach. IRL Press, Oxiord

Nikaido H, Vaara M (1985) Molecular basis of bacterial outer membrane permeability. Microb Rev 49:1-32

Rosenbusch JP (1974) Characterization of the major envelope protein from Escherichia coli. J Biol Chem 249:8019-8029

Samuelson MO, Kirchman DL (1990) Degradation of adsorbed protein by attached bacteria in relationship to surface hydrophobicity. Appl Environ Microbiol 56: $3643-3648$

Smith DC, Simon M, Alldredge AL, Azam F (1992) Intense hydrolytic enzyme activity on marine aggregates and implications for rapid particle dissolution. Nature 359: $139-142$ 
Tanoue E (1997) Proteins in the sed-synthesis. In: Handa N, Tanoue $E$, Hama $T$ (eds) Biogeochemistry of marine organic matter. Terra Scientific Publishing Company, Tokyo (in press)

Tanoue E, lshii M. Midorikawa T (1996) Discrete dissolved and particulate proteins in oceanic waters. Limnol Oceanogr 41:1334-1343

Tanoue E, Nishiyama S, Kamo M. Tsugita A (1995) Bacterial membranes: possible source of a major dissolved protein in seawater. Geochim Cosmochim Acta 59:2643-2648

Editorial responsibility: Fereidoun Rassoulzadegan,

Villefranche-sur-Mer, France
Tranvik LJ, Sherr EB, Sherr BF (1993) Uptake and utilization of 'colloidal' DOM by heterotrophic flagellates in seawater. Mar Ecol Prog Ser 92:301-309

Weiss MS, Abele U, Weckersser J, Welte W, Shiltz E, Shulz GE (1991) Molecular architecture and electrostatic poperties of a bacterial porin. Science 254:1627-1630

Yamamoto S, Ishiwatari R (1989) A study of the formation mechanisms of sedimentary humic substances - Il. Protein-based melanoidin model. Org Geochem 14 $479-489$

Submitted: April 1, 1997, Accepted: July 2, 1997

Proofs received from author(s): September 4, 1997 